\title{
UK 'terrorist' fights science-course ban
}

A British resident who is under surveillance for suspected terrorist activities is being prohibited from taking secondary-school-level science courses by the government, Nature has learned.

The man, referred to as A.E., is contesting the decision in court, in what is believed to be the first case of its kind. The preliminary hearing over whether A.E. should be allowed to take AS-level courses in human biology and chemistry took place on 16 November at London's High Court. The UK Home Office, which has an order restricting A.E.'s actions and affiliations, argues that such coursework could be turned towards terrorism. His solicitors counter that the knowledge is public, and that the furthering of A.E.'s education poses no threat.

At the heart of the case is a simple question: should basic courses in science be treated as potential tools for terror when in the wrong hands?

To protect the suspect, A.E.'s name and much of his personal information have been withheld from the public. What is known is that he is an unemployed Iraqi national in his mid-thirties who studied medicine at university in his home country. The government suspects him of terrorist affiliations, and he is the subject of a 'control order' - a special legal instrument that places limits on his freedoms.

Control orders were introduced by the UK government under the 2005 Prevention of Terrorism Act as a way of restricting the activities of suspected terrorists when prosecution would mean "revealing sensitive and dangerous intelligence". Among other things, control orders can be used to impose curfews, travel bans and limits on a person's access to mobile phones and the Internet. Nationally, 14 individuals are currently subject to control orders.

Critics have lambasted the orders as a blatant infringement of civil liberties. Because the orders depend on classified information,

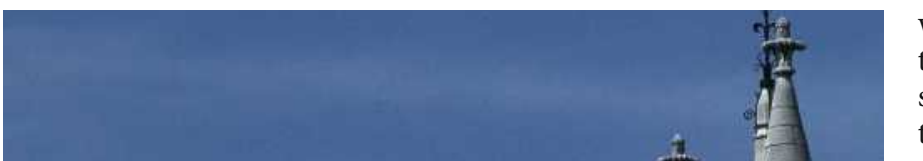

went unopposed, but when in September A.E. applied to take the two science courses, the government told him he could not enrol.

A Home Office spokeswoman was unable to comment because of the ongoing court case, but Ayub says the government fears that A.E. could turn his coursework towards terrorist ends.

Scientists contacted by Nature say that AS-level coursework would be unlikely to help a terrorist. The human-biology material includes basic theories of disease transmission, according to Neil Roscoe, head of education and training at the Institute of Biology in London. But there's no information on how to intentionally spread pathogens. "I'd say that there's very little in the chemistry course that would help a terrorist act," adds Colin Osborne, who heads education at the Royal Society of Chemistry.

Still, both Osborne and Roscoe say the courses would include some information that might be useful to someone interested in committing a terrorist act. The human-biology course includes a detailed examination of neurotoxins, for example. And chemistry labs would contain some dangerous compounds and teach basic techniques such as distillation. "If the government wants to be cautious, there are aspects that could be considered as aiding the cause," says Roscoe. On issues subjects rarely know what evidence is being brought against them. Furthermore, the subjects are never charged with a crime. That makes control orders virtually impossible to rebut, according to Gareth Crossman, director for policy at Liberty, a London-based civil-rights organization. "The whole system is totally unfair," he says.

Since 2006, A.E. has been under a control order that has limited his movements and affiliations, according to his lawyer, Mohammed Ayub of Chambers Solicitors in Bradford, UK. The order has made it impossible for A.E. to find work, says Ayub. So he instead sought to further his education. English-language courses of science and security, he adds, "there's never going to be an easy answer".

But other scientists remain unconvinced. Peter Atkins, emeritus professor of physical chemistry at the University of Oxford, says the techniques taught in the course are simple: "Anybody with an interest in cooking could do them."

Ayub maintains that A.E.'s only interest in the classes is to return to university and continue his medical education. Ayub, himself a former oncologist, points out that A.E.'s level of knowledge is already well beyond an AS-level course. "It's absurd," he says.

The case will continue in the new year, with a ruling expected in the spring.

Geoff Brumfiel 